\section{The Assessment of the}

\section{Relationship between}

\section{Problematic Internet Use}

\section{and Parent-Adolescent}

\section{Relationship Quality,}

\section{Loneliness, Anger, and}

\section{Problem Solving Skills}

\section{ABSTRACT}

The assessment of the relationship between problematic internet use and parent-adolescent relationship quality, loneliness, anger, and problem solving skills

Objective: The main purpose of this study was to investigate relationships between problematic internet use, and parent-adolescent relationship quality, loneliness, anger, and problem solving skills. Another aim of the current study was to find out differences related to sociodemographic variables, such as gender and socioeconomic status in problematic internet use.

Method: The sample was composed of 402 university students. Online Cognition Scale, Parent-Adolescent Relationship Quality Scale, UCLA Loneliness Scale, Problem Solving Inventory and Multidimensional Anger Inventory were used. The statistical analysis of data was conducted by using correlation analysis, analysis of variance (ANOVA), and multiple mediation model test (Bootstrap).

Results: The results revealed that $16.4 \%$ of participants had high scores on problematic internet use, and spent 2.7 hours $(\mathrm{SD}=1.23)$ a day on the internet on average. Males had higher levels of problematic internet use when compared to females. The results of mediating effects of anger, problem solving, and loneliness on relationship quality between parent-adolescents, and problematic internet use revealed that these variables partially mediated the relationship between negative mother-adolescent relationship and problematic internet use.

Discussion: These results provide helpful tips that can be used in the prevention and intervention programs related to problematic internet use. Psychological counseling and psychotherapy in practice may include strengthening the relationship between adolescents with problematic internet use and their parents. Moreover, following the assessment of their loneliness, and anger levels, and problem solving skills, interventions related to communications skills, anger management, and problem solving approaches may decrease their problematic internet use.

Keywords: Anger, internet, loneliness, problem solving

\section{ÖZET}

Problemli internet kullanımı ile ebeveyn-ergen ilişki niteliği, yalnızık, öfke ve problem çözme becerileri arasındaki ilișkilerin incelenmesi

Amaç: Çalışmanın temel amacı, problemli internet kullanımı ile ebeveyn-ergen ilişki niteliği, yalnızlık, öfke ve problem çözme becerileri arasındaki ilişkilerin incelenmesidir. Ayrıca problemli internet kullanımının cinsiyet ve sosyo-ekonomik düzey gibi sosyodemografik değişkenler açısından nasıl farklllaşıı̆ıııın belirlenmesi de diğer bir amaç̧ıı. Yöntem: Çalışmanın örneklemini 402 üniversite öğrencisi oluşturmaktadır. İnternette Bilisşsel Durum Ölçeği, EbeveynErgen Iliş̧i Niteliği Ölçeği, UCLA Yalnılılk Ölçeği, Problem Çözme Envanteri ve Çok Boyutlu Öfke Ölçeği kullanılmışıır. Elde edilen veriler; korelasyon, varyans analizi (ANOVA) ve çoklu araclı model testi (Bootstrap) gibi istatistik analiz yöntemleri ile incelenmiştir.

Bulgular: Örneklemin \%16.4'ünün problemli internet kullanımı puanlarının yüksek olduğu ve bu bireylerin günde ortalama 2.7 (SS=1.23) saat internet kullandıkları belirlenmiştir. Erkeklerin kadınlara oranla daha çok problemli internet kullanımına sahip oldukları bulunmuștur. Çalıșmada ebeveyn-ergen ilișki niteliği ile problemli internet kullanımı arasında öfke, problem çözme ve yalızllık değişkenlerinin aracı etkisine bakılmış ve bu değişkenlerin olumsuz anne-ergen ilişkisi ile problemli internet kullanımı arasındaki ilișkide "kısmi aracılık" etkileri olduğu bulunmuștur. Yine aynı aracı değișkenler olumsuz baba-ergen ilişkisi ile problemli internet kullanımı arasındaki ilişkide de "kısmi aracıllk" rolünü üstlenmişlerdir. Tartışma: Elde edilen bulgular, problemli internet kullanımının önlenmesive tedavisine yönelikmüdahale programlarında kullanılabilecek yararı ipuçları sağlamaktadır. Psikolojik danışma ve psikoterapi uygulamalarında, problemli internet kullanımı olan bireylerin ebevynleriyle ilişkilerinin güçlendirilmesi sağlanabilir. Ayrıca bu bireylerin yalnızlık ve öfke düzeyleri ile problem çözme becerileri de değerlendirilerek; iletişim becerileri, öfke kontrolü ve problem çözme yaklaşımları gibi alanlarda yapılacak müdahahleler problemli internet kullanımının azaltılmasında etkili olabilir Anahtar kelimeler: Öfke, internet, yalnızlk, problem çözme
Address reprint requests to / Yazışma adresi: Aysegul Durak Batigun,

Ankara University, Faculty of Languages, History, and Geograhy, Department of Psychology, Sihhiye/Ankara, Turkey

Phone / Telefon: +90-312-310-3280/1231

E-mail address / Elektronik posta adresi: batigun@ankara.edu.tr

Date of receipt / Geliş tarihi: April 6, 2016 / 6 Nisan 2016

Date of the first revision letter / illk düzeltme öneri tarihi: April 25, 2016 / 25 Nisan 2016

Date of acceptance / Kabul tarihi: May 12, 2016 / 12 Mayıs 2016 


\section{INTRODUCTION}

$\mathrm{I}_{100}^{\mathrm{nnt}}$ ternet is one of the most significant and effective tools that science has inserted in our lives. In recent years, as smart phones have became largely available, reaching internet is much easier and number of users is increased. Although increasing use of internet overtime have positive effects, it has brought also addiction/ abuse problems of users with itself. Young used the internet addiction, and he developed diagnostic criteria based on diagnostic criteria of "pathological gambling" in DSM-IV (1). In many studies conducted according to these criteria, it was determined that males developed addiction more than females (2-4), and it was noted that addiction was more commonly parallel with the most frequent internet-use age, which was adolescence $(5,6)$. In the literature, there are different terms like "internet addiction", "internet abuse", and "problematic internet use". In the present study, terminology of problematic internet use is preferred.

Widespread problematic internet use increases the interest in this issue, and leads to investigate many variables which may be related. One of these variables is the parent-adolescent relationship quality, which reflects attitudes originated from the history of their relationship (7). The most powerful risk factor was defined as poor parent-adolescent relationship in leading emotional and behavioral problems in adolescents (8). In a study, it was noted that university students who were problematic internet users defined their mothers less protective and close. Moreover, these students reported that both of their parents were over-controlling (6). It was believed that adolescents who could not receive support from their families used internet as a support to cope with this situation (9). In a study from Turkey, problematic internet use scores of adolescents who had parents with attitudes defined as "uninterested", were determined higher (10).

The other variable known to be related to problematic internet use is loneliness, which is defined as absence of social relationships of individuals or a reaction to absence of closeness, intimidation and emotionality in these social relationships (11). It was commonly emphasized that loneliness was a variable related to problematic internet use (12-14). It is also known that lonely individuals use internet mostly to meet new people, and to communicate with individuals who have similar fields of interests (15).

Anger is a variable which is known to be related to problematic internet use. In psychology dictionary, it is defined as "an intense, and negative feeling caused in conditions such as frustration, being attacked or threatened, and which may generally end up in somehow hostile behaviors against individuals or conditions" (16). In a study, individuals who are internet addicted, alcohol addicted, and healthy control group were compared for anger factor, and it was determined that anger expression related to hostility was higher in the internet addicted group (17). In two different studies performed in Turkey, it was reported that as problematic internet use was increased, anger expressions got worse (18), and there was a significant correlation between one type of anger expression, selfdirected anger, and internet addiction (19).

In the present study, another factor examined was problem solving ability, which is defined as a cognitivebehavioral process during which different effective solution alternatives are prepared, and the probability of choosing the most effective alternative is increased (20). Although problematic internet use may cause many familial, occupational, social, and physical problems (21), individuals cannot prevent themselves from entering the internet, and they have troubles to solve this problem. It seemed that people were using internet more to escape from problems rather than solving. When the literature was reviewed, it was observed that there were few numbers of studies investigating problematic internet use and problem solving abilities. It was concluded after reviewing limited number of studies about this issue that both variables were related to each other (22).

As it is understood from the literature mentioned above, there are different variables related to problematic internet use. Among these variables, parent-adolescent relationship quality, loneliness, anger, and problem solving abilities have been investigated in various studies. Although there are many studies related to loneliness and anger variables, 
there are limited number of studies in parent-adolescent relationship quality, and problem solving abilities especially in Turkey. Moreover, there is no study which have investigated these four variables (parentadolescent relationship quality, loneliness, anger, and problem solving abilities) related to internet addiction. In this context, the obtained data may be helpful in prevention of problematic internet use, which is becoming a widespread issue, and developing intervention programs for treatment. For example, problematic internet use may be tried to be decreased by interventions which evaluate parent-individual relationship quality, loneliness, anger levels, and problem solving ability of individuals during psychological consultancy and psychotherapy in practice.

Therefore, the aim of the study was determined as evaluation of correlations between problematic internet use and parent-adolescent relationship quality, loneliness, anger and problem solving ability. In the context of basic aim of the present study, responses to below mentioned questions were investigated:

1. Is there any significant effect of gender variable on problematic internet use?

2. Is there any significant effect of socio-economic level on problematic internet use?

3. Is there any mediating effects of loneliness variable between parent-adolescent relationship quality and problematic internet use?

4. Is there any mediating effects of anger variable between parent-adolescent relationship quality and problematic internet use?

5. Is there any mediating effects of problem solving between parent-adolescent relationship quality and problematic internet use?

\section{METHOD}

Sampling of the study was constituted from undergraduate students who were attending at Hacettepe University, Ankara University, Kirikkale University, Gazi University, and Middle East Technical University, and were selected by easily accessible sampling technique. Participants who did not respond to the majority of questions, and marked "yes" in the information form to "have had any psychiatric disease within the last 6 months?" were excluded from the study. As individuals who received three points were excluded from the study sample, data analysis was performed on a total of 402 students.

Of participants, 234 (60.4\%) were females, and 159 $(39.6 \%)$ were males, and their age range was 17-25 years $(\bar{X}=20.59, S D=1.85)$. When the education level of mothers of participants was investigated, mothers of $168(41.8 \%)$ were graduated from the primary school, $50(12.4 \%)$ were graduated from the secondary school, $88(21.9 \%)$ were graduated from the high school, and $83(20.6 \%)$ were graduate from the university. The education level of mothers of 13 participants (3.3\%) could not be determined.

\section{Measures}

Personal Information Form: This was a form prepared to determine demographic characteristics such as age, gender, education level of mother, and participant's university by investigators. Also there were questions to collect information about from where the participants entered the internet, the mean duration of daily internet use, and most common reasons of their internet use.

Online Cognition Scale (OCS): It was a Likert type scored scale (from 1 to 7) with 36 items which was developed to measure problematic internet use by Davis et al. (23). High scores indicated that problematic internet use had high rates. Its adaptation in Turkish was performed by Ozcan and Buzlu (24), and Cronbach's alpha internal consistency coefficient was 9.91, whereas test-retest reliability coefficient was determined as 0.90 for the scale.

Parent-Adolescent Relationship Quality (PARQ): It is a 5-point Likert type scale with 18 items which has been developed by Wissink et al. (25). Each item in the scale is evaluated both for the mother and father, and separate scores are collected for both parents. The validity study of the scale was performed 
in Turkey among students attending the primary and secondary schools by Duru et al. (26). The validity and reliability study for university students were performed by Batigun and Say (27), and a 3-factor structure was obtained for mother and father forms as "Explanation", "Negative mother/father relationship", and "Positive mother/father relationship". Cronbach's alpha reliability coefficients of these factors ranged between 0.85 and 0.92 .

UCLA Loneliness Scale: It is a 4-point Likert type scale with 20 items, which has been developed by Russell et al. (28). High scores indicate that loneliness level is high. Turkish validity study was performed by Demir (29), and Cronbach's alpha and test-retest reliability coefficients were determined as 0.96 , and $r=0.94(p<0.001)$, respectively.

Multidimensional Anger Inventory (MAI): The scale was developed to measure anger with various dimensions by Balkaya and Sahin (30), and it scored Likert type between 1 and 5 points. Cronbach's alpha reliability coefficients of dimensions ranged between 0.83 and 0.93. In the present study, 4 dimensions as Anger Symptoms, Factors Causing Anger, Behaviors Related to Anger, and Interpersonal Anger were used. There are sufficient evidences related to validity and reliability of the scale.

Problem Solving Inventory (PSI): It is a 6-point Likert type scale with 35 items which was developed by Heppner and Petersen (31). Turkish validation was performed by Sahin et al. (32). The higher the total points obtained from the scale, the more the individual feels him/herself insufficient in problem solving abilities. Cronbach's alpha reliability coefficient was 0.88 , and the obtained reliability coefficient was determined as $r=0.81$ $(p<0.001)$ by using halving technique.

\section{Procedure}

A battery was formed in the study by collecting the scales. Firstly Informed Consent Form and Personal Information Form were applied to participants and then other scales were applied after sorting in the order to control the sequence effect. Local Ethics Committee approval was obtained from the related university (Decision No:11/148). Scales were applied to participants in their classrooms after informing them about the study and obtaining their informed consents. The application duration of scales was approximately 30-40 minutes. Before analysis, data were reviewed and data cleaning was performed. Firstly, data frequency was measured for each measuring tool, minimum and maximum values were examined, and participants not having $z$ values between -3 and +3 were excluded from the study. Obtained data were examined by statistical analysis methods such as correlation variance analysis (ANOVA), and model with multiple mediator test (Bootstrap). Bootstrap method was chosen because it gave more correct results in small sample sizes; it did not require to satisfy normal distribution hypothesis; it enabled evaluation of effects of multiple-directed mediated variables both separately and concomitantly; and it could define whether mediatory variables could function independently from each other $(33,34)$.

\section{RESULTS}

\section{Results Related to Internet Use}

It was determined that the mean duration of internet use among students was 2.03 hours $(\mathrm{S}=0.95)$. Nearly half of participants (49.5\%) spared 3 to 5 hours to use internet. While $23.9 \%$ of the sample used internet both for communication and providing knowledge, $54.0 \%$ reached internet through their cellular phones. It was observed that there was an equal distribution of causes of internet use. It was noted that number of participants using some websites for a short-time duration (50.0\%), and using a few websites for a longer time $(50.0 \%)$ were equal. The correlation coefficient between problematic internet use and daily duration of internet use was 0.36 $(p<0.001)$, whereas the correlation coefficient between problematic internet use and social sharing sites was determined as $0.33(p<0.001)$. 
In the study context, the means of sample scores which are obtained in OCS, and participants who received scores (120.30) one standard deviation (30.00) above the mean value (90.30) were accepted as "higher problematic internet user", whereas who received scores one standard deviation below (60.30) were accepted as "lower problematic internet user". In the present study, 66 participants received scores one standard deviation above the mean, which indicated that their problematic internet use was higher. These participants made up of $16.4 \%$ of the sample, and they used internet $2.7(\mathrm{SD}=1.23)$ hours in a day.

\section{Results Related to Sociodemographic Variables}

To determine whether scores obtained from OCS differed according to gender and socioeconomic level (SEL), the marker was defined as education level of the mother. After participants with mothers graduated from the primary school were classified as "low SEL", from the secondary and high school were classified as "moderate SEL", and from university were classified as "high SEL"; two variable variation analysis (ANOVA) of "gender (2) x SEL (3)" was performed. At the end of the analysis, it was determined that gender $\left(\mathrm{F}_{1-378}=5.41, \mathrm{p}<0.05\right)$ variable had basic effect on scores obtained from OCS. According to the obtained results males (Mean=93.99, $\mathrm{SD}=30.75$ ) had higher rates of problematic internet use than females (Mean=87.86, SD=28.62). SEL variable did not have a basic effect $\left(\mathrm{F}_{2-378}=0.03, \mathrm{p}>0.05\right)$. Additionally, there was no interventional effect $\left(\mathrm{F}_{2-378}=1.64, \mathrm{p}>0.05\right)$.

\section{Correlation Analyses}

Pearson's correlation coefficients calculated between variables are shown in Table 1. As shown, correlation coefficients between OCS and PARO subscales, anger dimensions, PSI, and UCLALoneliness Scale ranged from $(-0.12) \mathrm{p}<0.01$ to 0.27 $(p<0.001)$. Coefficients between total anger score and PSI and UCLA-Loneliness Scale were $0.13(p<0.01)$, and $0.23(p<0.001)$, respectively.

\section{Mediatory Variable Analyses}

Bootstrap method which is a multiple mediated model test (34) to measure mediatory roles of anger, loneliness, and problem solving abilities between problematic internet use and parent-adolescent relationship quality, and was proposed by Preacher and Hayes (33) was used in the study. Due to mediatory model test, correlations between predictive variables (subdimensions related to parents) and predicted variables (problematic internet use) were investigated, and analysis was performed between correlated

Table 1: Correlation coefficients between variables

\begin{tabular}{|c|c|c|c|c|c|c|c|c|c|c|c|c|c|}
\hline & 2 & 3 & 4 & 5 & 6 & 7 & 8 & 9 & 10 & 11 & 12 & 13 & 14 \\
\hline 1 & 0.01 & $0.24^{* * *}$ & $-0.12^{* *}$ & $0.20^{* * *}$ & -0.10 & -0.03 & $0.27^{* * *}$ & 0.07 & $0.27^{* * *}$ & $0.18^{* * *}$ & $0.18^{* * *}$ & $0.21^{* * *}$ & $0.23^{* * *}$ \\
\hline 2 & - & -0.03 & $0.70^{* * *}$ & 0.07 & $0.32^{* * *}$ & $0.62^{* * *}$ & -0.01 & 0.10 & -0.04 & $-0.11^{* *}$ & 0.01 & -0.07 & $-0.20^{* * *}$ \\
\hline 3 & - & - & $-0.22^{* * *}$ & $0.47^{* * *}$ & $-0.15^{* *}$ & -0.05 & $0.24^{* * *}$ & -0.01 & $0.21^{* * *}$ & $0.26^{* * *}$ & $0.20^{* * *}$ & $0.18^{* * *}$ & $0.17^{* * *}$ \\
\hline 4 & - & - & - & -0.05 & $0.54^{* * *}$ & $0.44^{* * *}$ & -0.07 & 0.07 & $-0.12^{* *}$ & -0.08 & -0.05 & -0.09 & $-0.25^{* * *}$ \\
\hline 5 & - & - & - & - & $-0.28^{* * *}$ & 0.02 & $0.21^{* * *}$ & 0.03 & $0.18^{* * *}$ & $0.21^{* * *}$ & $0.19^{* * *}$ & 0.18 & 0.10 \\
\hline 6 & - & - & - & - & - & $0.66^{* * *}$ & $-0.11^{* *}$ & -0.01 & $-0.15^{* *}$ & -0.05 & $-0.10^{*}$ & -0.09 & $-0.16^{* * *}$ \\
\hline 7 & - & - & - & - & - & - & -0.01 & 0.03 & -0.06 & -0.08 & -0.03 & -0.07 & $-0.18^{* * *}$ \\
\hline 8 & - & - & - & - & - & - & - & $0.31^{* * *}$ & $0.45^{* * *}$ & $0.45^{* * *}$ & $0.64^{* * *}$ & $0.21^{* * *}$ & $0.13^{* *}$ \\
\hline 9 & - & - & - & - & - & - & - & - & $0.38^{* * *}$ & $0.19^{* * *}$ & $0.74^{* * *}$ & -0008 & $-0.24^{* * *}$ \\
\hline 10 & - & - & - & - & - & - & - & - & - & $0.47^{* * *}$ & $0.84^{* * *}$ & $0.14^{* *}$ & 0.04 \\
\hline 11 & - & - & - & - & - & - & - & - & - & - & $0.63^{* * *}$ & $0.29^{* * *}$ & 0.06 \\
\hline 12 & - & - & - & - & - & - & - & - & - & - & - & $0.13^{* *}$ & -0.05 \\
\hline 13 & - & - & - & - & - & - & - & - & - & - & - & - & $0.23^{* * *}$ \\
\hline \multicolumn{4}{|c|}{$\begin{array}{l}\text { 1. Online Cognitive Scale } \\
\text { 2. Mother's Explanation } \\
\text { 3. Negative Mother-Adolescent Relationship } \\
\text { 4. Positive Mother-Adolescent Relationship }\end{array}$} & \multicolumn{4}{|c|}{$\begin{array}{l}\text { 5. Negative Father-Adolescent Relationship } \\
\text { 6. Positive Father-Adolescent Relationship } \\
\text { 7. Father's Explanation } \\
\text { 8. Signs of Anger }\end{array}$} & \multicolumn{3}{|c|}{$\begin{array}{l}\text { 9. Factors Related to Anger } \\
\text { 10. Interpersonal Anger } \\
\text { 11. Behaviors Related to Anager }\end{array}$} & \multicolumn{3}{|c|}{$\begin{array}{l}\text { 12. Total Score of Anger Scale } \\
\text { 13. Problem Solving Ability Inventory } \\
\text { 14. UCLA Loneliness Scale }\end{array}$} \\
\hline
\end{tabular}




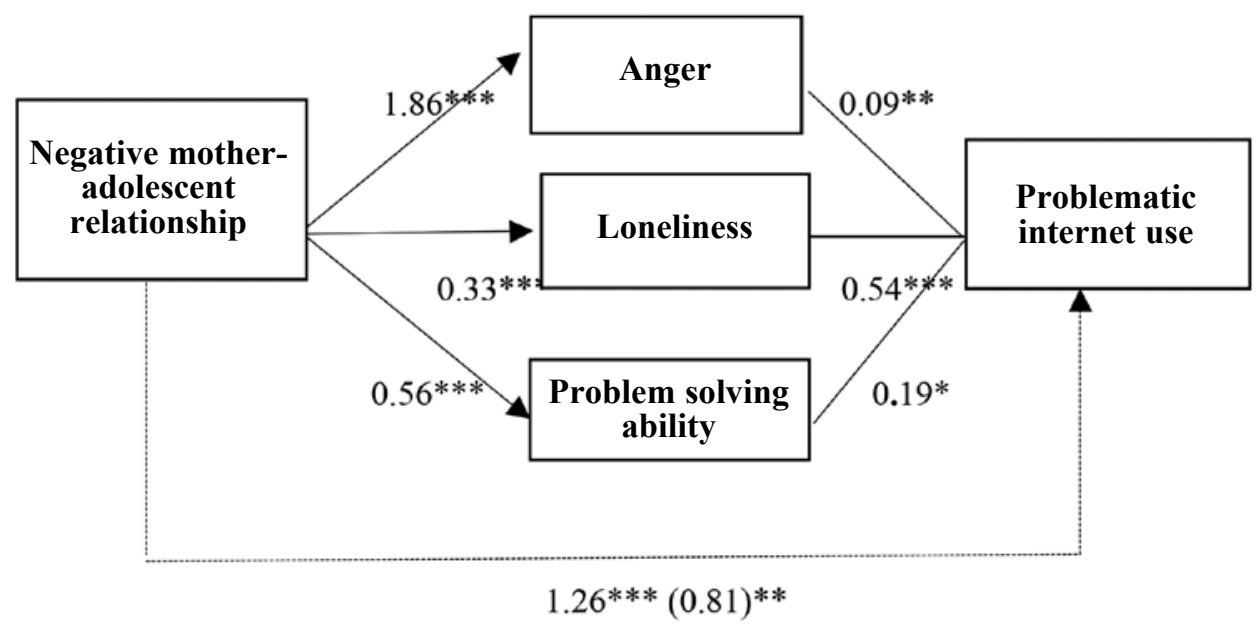

Figure 1: Mediatory roles of anger, loneliness, and problem solving ability scores between parent-adolescent relationship, and problematic internet use.

Non-standardized beta values are given in the figure. ${ }^{*} \mathrm{p}<0.05,{ }^{* *} \mathrm{p}<0.01,{ }^{* * *} \mathrm{p}<0.001$.

Table 2: Point Estimations and confidence intervals for total and specific effects on problematic internet use

\begin{tabular}{lcccccc} 
& \multicolumn{3}{c}{$\begin{array}{c}\text { Multiplication of Coefficients } \\
\text { (Product of coefficients) }\end{array}$} & \multicolumn{2}{c}{$\begin{array}{c}\mathbf{9 5 \%} \text { BCa Confidence } \\
\text { Interval }\end{array}$} \\
\cline { 2 - 7 } Variable & Point Estimation & $\mathbf{S E}$ & $\mathbf{z}$ & $\mathbf{p}$ & Low & High \\
\hline Total & $\mathbf{0 . 4 5}$ & $\mathbf{0 . 1 1}$ & $\mathbf{4 . 0 9}$ & $<\mathbf{0 . 0 0 1}$ & $\mathbf{0 . 2 5 8 2}$ & $\mathbf{0 . 7 0 9 7}$ \\
Anger & 0.16 & 0.07 & 2.44 & 0.01 & 0.0555 & 0.3429 \\
Loneliness & 0.18 & 0.06 & 1.88 & 0.06 & 0.0564 & 0.2699 \\
Problem Solving Abilities & 0.11 & 0.08 & 2.56 & 0.01 & 0.0195 & 0.3502 \\
\hline
\end{tabular}

BCa: (Bootstrap Method) bias corrected accelerated

variables. In this context, as EIN mother explanation and favorable mother-adolescent subdimensions with father explanation and favorable father-adolescent relationship subdimensions had no significant correlations, they were excluded from the analysis.

In the context of the study, total scores of MAI, UCLA-Loneliness Scale, and PSI were accepted as variables. Correlations between predictive variables and mediatory variables, and also predicted variable and mediatory variables were examined. As there were significant correlations between them they were included in the analysis.

Signs which were related to mediatory effects of negative mother-adolescent relationship and problematic internet use such as anger, loneliness, and problem solving are shown in Figure 1. As shown in Figure 1, negative mother-adolescent relationship had direct effect on predictive variable of problematic internet use $(B=1.26, t=4.71, p<0.001)$. Direct effects of negative mother-adolescent relationship were determined on anger $(\beta=1.86, t=4.01, p<0.01)$, loneliness $(\beta=0.33, t=3.36, p<0.001)$, and problem solving abilities $(B=0.56, t=3.53, p<0.001)$. Moreover, it was determined that anger $(\beta=0.09, t=3.07, p<0.01)$, loneliness $(B=0.54, t=3.92, p<0.001)$ and problem solving abilities $(B=0.19 \mathrm{t}=0.2 .21, \mathrm{p}<0.05)$ had significant and direct effects on problematic internet use. When negative mother-adolescent relationship and anger, loneliness, and problem solving abilities were included in the equation concomitantly, it was observed that the relationship between negative mother-adolescent relationship and problematic internet use was decreased $(B=0.81, t=3.01, p<0.01)$. In this context, it was concluded that mediatory variables of anger, loneliness, and problem solving abilities had "partial mediatory" effects between negative motheradolescent relationship and problematic internet use. Besides, it was observed that the model was significant 


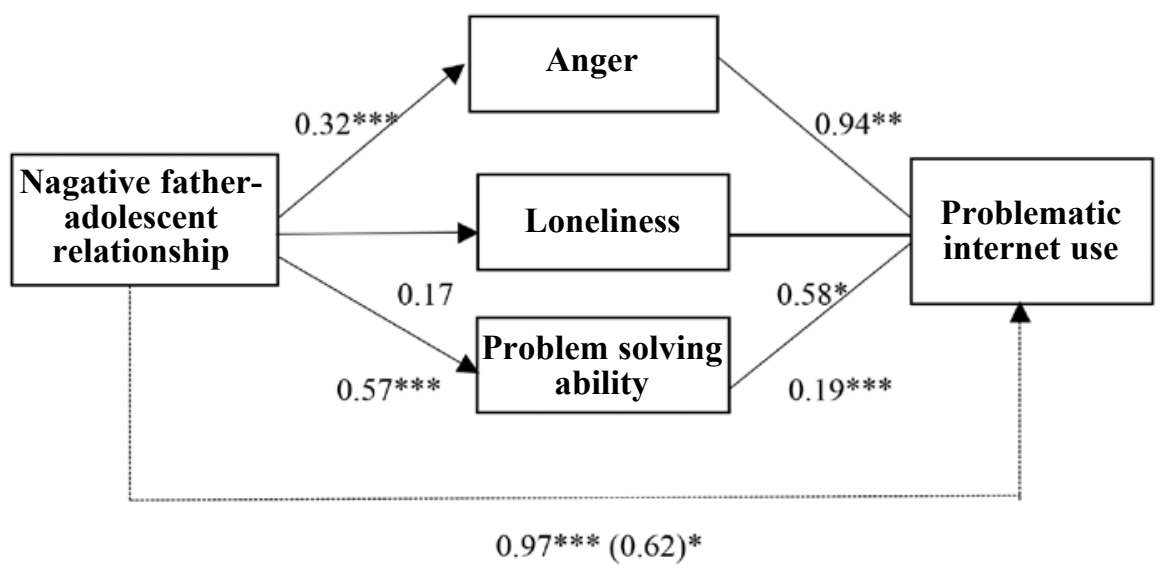

Figure 2: Mediatory roles of total scores of anger, loneliness, and problem solving ability between parent-adolescent relationship, and problematic internet use.

Non-standardized beta values are given in the figure. ${ }^{*} \mathrm{p}<0.05,{ }^{* *} \mathrm{p}<0.01,{ }^{* * *} \mathrm{p}<0.001$.

$\left(\mathrm{F}_{4-374}=14.59, \mathrm{p}<0.001\right)$, and variation was $13 \%$. Presence of any partial mediation effects of mediatory variables were investigated on 1000 individuals of bootstrap sampling, and the results are given in Table 2 . As it was shown in Table 2, total indirect effects of three mediatory variables were determined significant (point estimation $=0.45$ and $95 \%$ BCa CI [0.2582-0.7097]). If each mediatory variable was examined separately, significant partial mediatory effects were determined between parent-adolescent relationship and problematic internet use, and anger (point estimation $=0.17$ and 95\% BCa CI [0.0555- 0.3429]), loneliness (point estimation $=0.18$ and $95 \% \mathrm{BCa} C \mathrm{CI}$ [0.0564-0.3502]), problem solving abilities (point estimation $=0.11$ and 95\% BCa CI [0.0195-0.2699]).

Signs of mediatory effects caused by anger, loneliness, and problem solving abilities on relationships between negative-adolescent relationship and problematic internet use are shown in Figure 2. As shown in Figure 2, negative father-adolescent relationship had direct effect on predicted variable, problematic internet use $(\beta=0.97, t=3.81, p<0.001)$. Although negative father-adolescent relationship had direct effects on mediatory anger $(B=0.32, t=3.71$, $p<0.001)$ and problem solving abilities $(\beta=0.57, t=3.56$, $p<0.001)$; no significant direct effect was determined on loneliness ( $\beta=0.17, t=0.10, p>0.05$ ). It was determined that there were statistically significant effects between mediatory variables, anger $(B=0.94, t=3.24, p<0.01)$, loneliness $(B=0.58, t=4.24, p<0.05)$, and problem solving abilities $(B=0.19, \mathrm{t}=4.24, \mathrm{p}<0.001)$ and problematic internet use. When negative father-adolescent relationship and all mediatory variables were included in the equation concomitantly, then correlation between negative father-adolescent relationship problematic internet use was decreased ( $B=0.62, t=2.46, p<0.05$ ). In this context, it was concluded that mediatory variables had "partial mediatory" effects between fatheradolescent relationship and problematic internet use. Additionally, it was observed that all of the model was significant $\left(\mathrm{F}_{4-374}=13.74, \mathrm{p}<0.001\right)$ and the variation explained $12 \%$.

It is examined on the bootstrap sample of 1000 individuals, whether partial mediatory effects are significant, and the results is given in Table 3. As seen in Table 3, total indirect effects of three mediatory variables were significant (point estimation $=0.35$ and $95 \%$ BCa CI [0.1170-0.5607]). If each variables of anger (point estimation $=0.15$ and $95 \%$ BCa CI [0.0483-0.2997]) and problem solving abilities (point estimation $=0.10$ and 95\% BCa CI [0.0172-0.2339]) are evaluated separately, it is observed that each had significant partial correlation between father-adolescent relationship and problematic internet use, but partial mediatory effect of loneliness (point estimation $=0.10$ and $95 \%$ BCa CI [-0.0001-0.2538]) is insignificant. 
Table 3: Point Estimations and confidence intervals for total and specific effects on problematic internet use

\begin{tabular}{|c|c|c|c|c|c|c|}
\hline \multirow[b]{2}{*}{ Variable } & \multicolumn{4}{|c|}{$\begin{array}{l}\text { Multiplication of Coefficients } \\
\text { (Product of coefficients) }\end{array}$} & \multicolumn{2}{|c|}{$\begin{array}{l}\text { 95\% BCa Confidence } \\
\text { Interval }\end{array}$} \\
\hline & Point Estimation & SE & $\mathbf{z}$ & $\mathbf{p}$ & Low & High \\
\hline Total & 0.35 & 0.10 & 3.50 & $<0.001$ & 0.1770 & 0.5607 \\
\hline Anger & 0.15 & 0.06 & 2.45 & 0.01 & 0.0483 & 0.2997 \\
\hline Lonelines & 0.10 & 0.06 & 1.65 & 0.06 & -0.0001 & 0.2538 \\
\hline Problem Solving Abilities & 0.10 & 0.05 & 1.88 & 0.01 & 0.0172 & 0.2339 \\
\hline
\end{tabular}

BCa: (Bootstrap Method) bias corrected accelerated

\section{DISCUSSION}

Primarily, relationships between characteristics of internet use and problematic internet use were investigated. The correlation analyses revealed positive correlations between daily duration of internet use, daily duration of social sharing sites and total score of OCS. In such conditions, it may be said that individuals with problematic internet use spent more time in the internet and used social sharing sites more. There are previous studies supporting this finding in the literature (3,35-39). In another words, internet is more commonly used for interactions and amusement such as games and social media use, and as duration of internet use is increased, problematic internet use is also increased.

Additionally, rate of individuals with problematic internet use was determined as $16.4 \%$ in the study. There are many different rates about this issue in the literature. For example, while it was reported low rates as $1 \%$ (40) in some studies, rates reaching up to $19 \%$ (3) and $80 \%$ (1) were reported in some studies. It was reported that this condition was resulted from different factors used for definition of problematic internet use, but it was pointed that study methods might also be effective (41). In the present study, it might be considered that this ratio indicated areas with one standard deviation above for the mean OCS. In other words, the scale used was not standardized for the risk group, and such high ratios might not be observed while using such a standardized scale.

In the study, problematic internet use was also investigated for age and SEL variables, and it was determined that males had significantly higher score than females in OCS. There are many study results consistent with this finding $(2-4,42)$. This condition can be explained as males are more interested in technological improvements (43) or male use computers more commonly, and go to places like internet cafe more frequently (44). Moreover, it should also be considered that addiction is more commonly encountered among males.

In the present study, mediatory roles of anger, problem solving abilities, and loneliness were investigated between problematic internet use and parent-adolescent relationship quality. As a result of analyses, mediatory roles of three variables were determined between negative mother-adolescent relationship and negative father-adolescent relationship. It was shown in the related literature that these variables were closely related to problematic internet use. For example, Ahmadi and Saghafi (45) reported in their study that relationship quality of family was the most important factor in problematic internet use. Negative relationships with mothers were evaluated as a factor in internet addiction of the adolescent $(5,6)$. Additionally, there were studies emphasizing that negative relationship with the father was more effective than negative relationship with mother in problematic internet use (46). Besides, it was observed that if negative mother-adolescent relationship was the predictive variable, it was observed that loneliness had a partial mediatory effect. If there was negative father-adolescent relationship, then loneliness did not have partial mediatory effect. When the literature related to parent-adolescent relationship was reviewed, it was determined that adolescents had closer relationships with their mother than their fathers (46). Therefore, it might be told that adolescents had more limited relationships with their fathers. In the present study, 
it may be thought that mediatory effect of loneliness may differ according to mother and father in relationship with this issue. In such a way that, relationship with father is not close enough, so it decreases significance of negative relationship with the father, and it may remove mediatory effect of loneliness between negative father-adolescent and problematic internet use. However, warm relationship with the mother is a protective factor for loneliness, so it is more probable that loneliness may have a mediatory effect between mother-adolescent relationship and problematic internet use.

Relationships between parental attitudes and problem solving abilities are unknown (47). Problem solving ability of adolescents whose parents behave protective or authoritative is decreased. According to Sivrikaya et al. (48) problem solving ability was increased as familial social support was increased.

The literature reviewing about problematic internet use and anger is also supporting the study results. In other words, as problematic internet use was increased, anger level of individuals was also increased $(17,19,49)$. Besides, Muris et al. (50) claimed that parental growth styles were effective on anger and hostility. There are findings that insufficiency in familial functionality, insufficient parental interest on adolescents and parents showing their anger expressions increase anger behaviors in adolescents (51).

Problem solving ability was another variable which was investigated in the present study. As problematic internet use was increased, problems in problem solving were also increased. There are not many studies performed with these two variables together in the literature. In a small number of study, it was reported that there was a strong correlation between problematic internet use and problem solving ability (22).

In conclusion, these obtained data provide beneficial clues in prevention of problematic internet use, which is a common problem in our decade, and in development of intervention programs targeting the treatment. Strengthening relationships of individuals with problematic internet use and their parents may be provided in psychological consultancy and psychotherapy performances. Besides, interventions which will be performed to improve communication skills, anger control, and problem solving fields, may decrease in problematic internet use in these individuals by evaluating loneliness, and anger levels as well as their problem solving ability. Thus, it is believed that the present study may have significant contributions for healthcare professionals.

Relationships between problem solving ability and problematic internet use are very rarely investigated in the current literature. Therefore, it is believed that results of the present study will contribute to the related literature, and may be a resource for further studies.

Our study has some limitations. Firstly, majority of samples have been obtained from students attending universities in the city of Ankara, and no data was collected from other cities and universities. This limits the generalization of study results. Secondly, data have been collected by self-reporting scales, so there is the possibility that participants may respond in much more positive approaches. Moreover, there are many statements in scales applied to participants. This may have caused decreased concentration and motivation of participants.

\begin{tabular}{|l|l|}
\hline Contribution Categories & Name of Author \\
\hline Development of study idea & G.S. \\
\hline Methodological design of the study & G.S., A.D.B. \\
\hline Data acquisition and process & G.S. \\
\hline Data analysis and interpretation & G.S., A.D.B. \\
\hline Literature review & G.S. \\
\hline Manuscript writing & G.S., A.D.B. \\
\hline Manuscript review and revisation & G.S., A.D.B. \\
\hline
\end{tabular}

Conflict of Interest: Authors declared no conflict of interest.

Financial Disclosure: Authors declared no financial support. 


\section{REFERENCES}

1. Young KS. Internet addiction: The emergence of a new clinical disorder. Cyberpsychol Behav 2009; 1:237-244. [CrossRef]

2. Willoughby T. A short-term longitudinal study of internet and computer game use by adolescent boys and girls: prevalence, frequency of use, and psychosocial predictors. Dev Psychol 2008; 44:195-204. [CrossRef]

3. Batigun AD, Kilic N. Associations between internet addiction and personal characteristics, social support, psychological symptoms, and some socio-demographic variables. Turkish Journal of Psychology 2011; 26:1-10. (Turkish)

4. Ha Y, Hwang WJ. Gender differences in internet addiction associated with psychological health indicators among adolescents using a national web-based survey. Int J Ment Health Addict 2014; 12:660-669. [CrossRef]

5. Xu J, Shen LX, Yan CH, Hu H, Yang F, Wang L, Kotha SR, Ouyang F, Zhang LN, Liao XP, Zhang J, Zhang JS, Shen XM. Parent-adolescent interaction and risk of adolescent internet addiction: a population-based study in Shanghai. BMC Psychiatry 2014; 14:112. [CrossRef]

6. Yang CY, Sato T, Yamawaki N, Miyata M. Prevalance and risk factors of problematic internet use: a cross-national comparison of Japanese and Chinese university students. Transcult Psychiatry 2013; 50:263-279. [CrossRef]

7. Darling N, Steinberg L. Parenting style as context: an integrative model. Psychol Bull 1993; 113:487-496. [CrossRef]

8. Wang JN, Liu L, Wang L. Prevalence and associated factors of emotional and behavioural problems in Chinese school adolescents: a cross-sectional survey. Child Care Health Dev 2014; 40:319-326. [CrossRef]

9. Durkee T, Kaess M, Carli V, Parzer P, Wasserman C, Floderus B, Apter A, Balazs J, Barzilay S, Bobes J, Brunner R, Corcoran P, Cosman D, Cotter P, Despalins R, Graber N, Guillemin F, Haring C, Kahn JP, Mandelli L, Marusic D, Mészáros G, Musa GJ, Postuvan V, Resch F, Saiz PA, Sisask M, Varnik A, Sarchiapone M, Hoven CW, Wasserman D. Prevalence of pathological internet use among adolescents in Europe: demographic and social factors. Addiction 2012; 107:22102222. [CrossRef]

10. Cevik GB, Celikkaleli O. Adolescent's friends attachment and internet addiction according to gender, perception parents attitudes and parents educational levels. Journal of Cukurova University Institute of Social Sciences 2010; 19:225-240. (Turkish)

11. Weiss RS. Loneliness: The Experience of Emotion and Social Isolation. Cambridge: MIT Press, 1973.
12. Bozoglan B, Demirer V, Sahin I. Loneliness, self-esteem, and life satisfaction as predictors of Internet addiction: a cross-sectional study among Turkish university students. Scand J Psychol 2013; 54:313-319. [CrossRef]

13. Morsunbul U. The association of internet addiction with attachment styles, personality tarits, lonelines sand life satisfaction. International Journal of Human Sciences 2014; 11:357-372.

14. van den Eijnden RJ, Meerkerk GJ, Vermulst AA, Spijkerman R, Engels RC. Online communication, compulsive internet use, and psychosocial well-being among adolescents: a longitudinal study. Dev Psychol 2008; 44:655-665. [CrossRef]

15. Morahan-Martin J, Schumacher P. Lonileness and social use of internet. Comput Human Behav 2003; 19:659-671. [CrossRef]

16. Budak S. Psychology Dictionary. Ankara: Bilim ve Sanat Yayinlari, 2005. (Turkish)

17. Hwang JY, Choi JS, Gwak AR, Jung D, Choi SW, Lee J, Lee JY, Jung HY, Kim DJ. Shared psychological characteristics that are linked to aggression between patients with Internet addiction and those with alcohol dependence. Ann Gen Psychiatry 2014; 13:6. [CrossRef]

18. Ata EE, Akpinar S, Kelleci M. The relationship between students problematic internet usage and their anger expression manner. TAF Preventive Medicine Bulletin 2011; 10:473-480. [CrossRef] (Turkish)

19. Senormanci O, Konkan R, Guclu O, Senormanci G. Depression, loneliness, anger behaviours and interpersonal relationship styles in male patients admitted to internet addiction outpatient clinic in Turkey. Psychiatr Danub 2014; 26:39-45.

20. D'Zurilla TJ, Goldfried MR. Problem solving and behavior modification. J Abnorm Psychol 1971; 78:107-126. [CrossRef]

21. Goldberg I. Internet addictive disorder (IAD) diagnostic criteria, http://www.psycom.net/iadcriteria.html, 1997. Access date April 15, 2015.

22. Ekinci B. The relationship between problematic internet entertainment use and problem solving skills among university students. Int J Ment Health Addict 2014; 12:607-617. [CrossRef]

23. Davis RA, Flett GL, Besser A. Validation of a new scale for measuring problematic internet use: implications for pre-employment screening. Cyberpsychol Behav 2002; 5:331-345. [CrossRef]

24. Ozcan NK, Buzlu S. An assistive tool in determining problematic internet use: validity and reliability of the "Online Cognition Scale" in a sample of university students. Journal of Dependence 2005; 6:19-26. (Turkish) 
25. Wissink IB, Dekovic M, Meijer AM. Parenting behavior, quality of the parent-adolescent relationship, and adolescent functioning in four ethnic groups. J Early Adolesc 2006; 26:133-159. [CrossRef]

26. Duru AG, Ucanok Z, Topcu AE. Testing relationships between negative life events, parent-adolsecent relationship, and adolescent compliance in the context of family stress model: an observational study. Scientific Research Unit of Ankara University (Project No: 11B5358001), 2014. (Turkish)

27. Batigun AD, Say G. Quality of Parent-Adolescent Relationship Scale of psychometric properties on university students. Journal of Clinical Psychiatry 2015; 18:49-58. (Turkish)

28. Russell D, Peplau LA, Cutrona CE. The revised UCLA Loneliness Scale: concurrent and discriminant validity evidence. J Pers Soc Psychol 1980; 39:472-480. [CrossRef]

29. Demir A. Validity and reliability of UCLA Loneliness Scale. Turkish Journal of Psychology 1989; 7:14-18. (Turkish)

30. Balkaya F, Sahin NH. Multidimensional anger scale. Turk Psikiyatri Derg 2003; 14:192-202. (Turkish)

31. Heppner PP, Petersen CH. The development and implications of a personal problem-solving inventory. J Couns Psychol 1982; 29:66-75. [CrossRef]

32. Sahin N, Sahin NH, Heppner PP. Psychometric proporties of the problem solving inventory in a group of Turkish university students. Cognit Ther Res 1993; 17:379-396. [CrossRef]

33. Preacher KJ, Hayes AF. Asymptotic and resampling strategies for assessing and comparing indirect effects in multiple mediator models. Behav Res Methods 2008; 40:879-891. [CrossRef]

34. Hayes AF, Preacher KJ. Statistical mediation analysis with a multicategorical independent variable. Br J Math Stat Psychol 2014; 67:451-470. [CrossRef]

35. Choi YJ. Investigating Koreans' internet use patterns and motivations, and exploring vulnerability of internet dependency. Unpublished dissertation, 2001

36. Eldeleklioglu J, Vural-Batik M. Predictive effects of academic achievement, internet use duration, loneliness and shyness on internet addiction. Hacettepe University Journal of Education 2013; 28:141-152.

37. Bruno A, Scimeca G, Cava L, Pandolfo G, Zoccali RA, Muscatello MRA. Prevalance of internet addiction in a sample of southern Italian high school students. Int J Ment Health Addict 2014; 12 : 708-715. [CrossRef]

38. Hawi NS. Internet addiction among adolescents in Lebanon. Comput Human Behav 2012; 28:1044-1053. [CrossRef]
39. Batigun $\mathrm{AD}$, Hasta $\mathrm{D}$. Internet addiction: an evaluation in terms of loneliness and interpersonal relationship styles. Anatolian Journal of Psychiatry 2010; 11:213-219.

40. Bayraktar F, Gun Z. Incidence and correlates of internet usage among adolescents in North Cyprus. Cyberpsychol Behav 2007; 10:191-197. [CrossRef]

41. Yellowlees PM, Marks S. Problematic internet use or internet addiction? Comput Human Behav 2007; 23:1447-1453. [CrossRef]

42. Krishnamurthy S, Chetlapalli SK. Internet addiction: Prevalence and risk factors: A cross-sectional study among college students in Bengaluru, the Silicon Valley of India. Indian J Public Health 2015; 59:115-121. [CrossRef]

43. Servidio R. Exploring the effects of demographic factors, internet usage and personality traits on internet addiction in a sample of Italian university students. Comput Human Behav 2014; 35:8592. [CrossRef]

44. Horzum MB. Examining computer game addiction level of primary school students in terms of different variables. Education and Science 2011; 36:56-68. (Turkish)

45. Ahmadi K, Saghafi A. Psychosocial profile of Iranian adolescents' internet addiction. Cyberpsychology Behav Soc Netw 2013; 16:543-548. [CrossRef]

46. Liu OX, Fang XY, Zhou ZK, Zhang JT, Deng LY. Perceived parentadolescent relationship, perceived parental online behaviors and pathological internet use among adolescents: gender-specific differences. PloS One 2013; 8:e75642. [CrossRef]

47. Arslan G, Kabasakal Z. Investigation of relationships between attitudes of parent and problem solving skills of adolescents. Turkish Studies 2013; 8:33-42. [CrossRef] (Turkish)

48. Sivrikaya AH, Kaya M, Ozmutlu I. Investigating the relationship between university students' perceived social supports from family and friends and problem solving skills. Nigde University Jorunal of Psysical Education and Sport Sciences 2013; 7:28-33.

49. Ko CH, Yen JY, Liu SC, Huang CF, Yen CF. The associations between aggressive behaviors and internet addiction and online activities in adolescents. J Adolesc Health 2009; 44:598-605.

\section{[CrossRef]}

50. Muris P, Meesters C, Morren M, Moorman L. Anger and hostility in adolescents: relationships with self-reported attachment style and perceived parental rearing style. J Psychosom Res 2004; 57:257-264. [CrossRef]

51. Avci R, Gucray SS. An investigation of violent and nonviolent adolescents' family functioning, problems concerning family members, anger and anger expression. Educational Sciences: Theory \& Practice 2010; 10:45-76. 